\title{
SHAHABAT YANG DITERIMA RIWAYATNYA: KAJIAN TENTANG KUALITAS PRIBADI DAN KAPASITAS INTELEKTUAL (KE-DLABIT-AN DAN 'ADALAT AL-SHAHABAH)
}

\author{
Ach. Zayyadi \\ Dosen Tetap Universitas Nurul Jadid Paiton Probolinggo \\ achzayyadi@yahoo.co.id
}

\begin{abstract}
This paper used the method of librarian research and aims to reveal the companions of his history: the study of personal qualities and intellectual capacities (dlabit-an and 'Adalat al-Shahabah) In the hadith, it is explained about the urgency of friends in relation to the series transmission of hadith. Which, friends have an important role in the effort to transfer the religious information in the next period, so it can be said, without friends, the religious information will not reach the next period, even today. In this study concluded that there are two great views in the transmission of hadith. The first assumes that companions have a very qualified personal qualities that can not be doubted by anything. While the second, the classification and clarifying level of personal quality of friends affected by many factors. The quality of the traditions narrated by the Companions is not merely a matter of personal quality ('just), but the personal capacity (dhabith) of a transmitter becomes something very urgent for the implementation of a true and responsible doctrine.
\end{abstract}

Key Words : Dlabit and 'Adalat al-Shahabah

\begin{abstract}
Abstrak
Tulisan ini menggunakan metode penelitian pustaka (libraray research) dan bertujuan untuk mengungkap para shahabat yang diterima riwayatnya: kajian tentang kualitas pribadi dan kapasitas intelektual (ke-dlabit-an dan 'Adalat al-Shahabah) Dalam hadis, dijelaskan tentang urgensi sahabat berkaitan dengan rangkaian periwayatan hadis. Yang mana, sahabat mempunyai peranan penting dalam upaya mentransfer informasi relegius pada priode selanjutnya, sehingga dapat dikatakan, tanpa sahabat maka informasi agama tidak akan sampai pada priode selanjutnya, bahkan sampai saat ini. Dalam kajian ini menyimpulkan adanya dua pandangan besar dalam periwayatan hadis. Pertama menganggap bahwa sahabat mempunyai kualitas pribadi yang sangat mumpuni yang tidak bisa diragukan dengan apapun. Sedangkan yang kedua, adanya klasifikasi serta klarisifikasi tingkat kualitas pribadi sahabat yang dipengaruhi oleh banyak faktor. Kualitas hadis yang diriwayatkan oleh para sahabat bukan hanya beracuan pada kualitas pribadi ('adil) saja, namun kapasitas pribadi (dhabith) seorang perawi menjadi sesuatu yang sangat urgen demi implementasi sebuah ajaran yang benar dan bertanggung jawab.
\end{abstract}

Kata kunci : Dlabit dan 'Adalat al-Shahabah 


\section{A. PENDAHULUAN}

Salah satu diantara sederetan musibah atau fitnah besar yang pernah menimpa umat Islam sejak abad pertama hijriah adalah tersebarnya hadits-hadits dha'if dan maudhu, di kalangan umat. Hal itu juga menimpa para ulama kecuali sederetan pakar hadis dan kritikus yang dikehendaki Allah seperti Imam Ahmad, Bukhari, Ibnu Muin, Abi Hatim ar-Razi, dan lain-lain. Tersebarnva hadits-hadits semacam itu di seluruh wilayah Islam telah meninggalkan dampak negatif yang luar biasa. Di antaranya adalah terjadinya perusakan segi akidah terhadap hal-hal gaib, segi syariat, dan sebagainya.Telah menjadi kehendak Ilahi Yang Maha Bijaksana untuk tidak membiarkan haditshadits semacam iru berserakan di sana-sini tanpa mengutus atau memberikan keistimewaan pada sekelompok orang berkemampuan. ${ }^{1}$

Albani menegaskan betapa bahayanya jika kemudian hadis dhoif dan mudhu' tersebar di kalangan ummat dan menjadikannya sebagai landasan hukum. Maka masalah ini pun selalu mendapat perhatian dari kalangan ulama hadis, pakar dan akademisi untuk selalu mengkaji dan membahasa hadis. Baik melalui pengajian kitab hadis yang disampaikan oleh Kyai, atau kajian hadis yang disampaikan oleh akademisi hadis di perguruan tinggi.

Salah satu kategori yang menjadi syarat shohihnya hadis adalah sanadnya shohih dan matan hadis hadis yang juga shohih. Para shahabat yang diterima riwayatnya: memiliki kualitas pribadi dan kapasitas intelektual (ke-dlabit-an dan

\footnotetext{
${ }^{1}$ Mohammad Nasiruddin Al-Bani, Silsilah hadis Dhoif dan Maudu'I (Jakarta :Gema Insani Press, 1995), h.29.
}

'Adalat). Secara Rinci Albani mengkategorikan pemenuhan segi kualitas pribadi ('adil atau 'adalah), bila telah (1) beragama Islam, (2) mukallaf (3) melaksanakan ketentuan Agama [Islam], dan (4) memelihara muru'ah, yang sejalan dengan patokan norma tentang orang jujur yang dapat diterima pemberitaannya.

Maka kajian ini akan menbahas secara terperinci tentang kualitas pribadi dan kapasitas intelektual (ke-dlabit-an dan 'Adalat). Perawi hadis yang akan menjadi masalah dan tujuan dari pada tulisan ini.

\section{B. KAJIAN TEORI}

1. Pengertian Sahabat

Secara epitimologis, kata "sahabat" berasal dari shahiba, bentuk pluralnya ashhab dan ashahib, yang mempnyai arti; menemani atau menyertai.

Kata shahiba seringkali digunakan untuk setiap orang yang menyertai orang lain dalam pergaulan hidup, baik penyertaan itu hanya sebentar saja maupun dalam waktu yang relativ lama ${ }^{2}$

Menurut istilah ahli hadis. Ialah,

$$
\text { كل مسلٍ راى رسول اله ص م }
$$

"setiap muslim yang dapat melihat Rasulullah"

Al Bukhari dalam kitab Shahihnya berkata
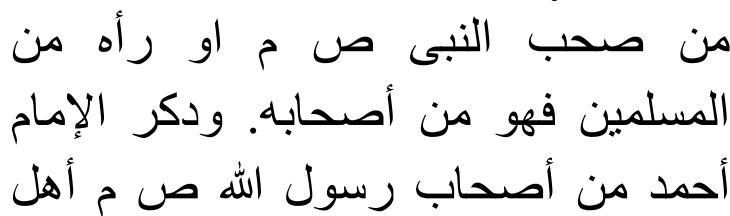
البدر. ثم قال : أفضل الناس بعد هوءلاء

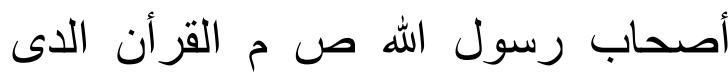
بعث فيهم. كل من صحبه سنة أو شهرا او

${ }^{2}$ Khaeruman, Badri, Otentisitas Hadis: Studi Kritik Atas Kajian Hadis Kontemporer, Bandung: PT. Remaja Rosdakarya, 2004. h. 77 


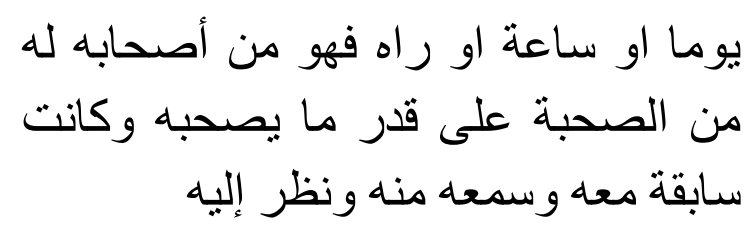

Artinya:

"orang menyertai Nabi atau melihatnya diatara orang-orang isla dipandang sahabatnya. Ahmad menerangkan bahwa diantara sahabat-sahabat Rasulullah adalah orang-orang yang turut bertempur dalam peperangan Badar. Kemudian dia berkata : orang-orang yang paling utama diantara Manusia sesudah sahabatsahabat Rasulullah, ialah yang hidup dalam abad Rasulullah diutus dalam kalangan mereka, segala orang yang melihat Rasulullah baik setahun, beberapa bulan, sehari ataupun hanya sesaat dapat melihatnya, digolongkan ke dalam golongan sahabatnya, dan berhak memperoleh menerima persahabatannya dengan Nabi menurut ukuran yang dapat menyertai nabi, dapat mendengar keterangan Nabi serta dapat memandangnya ${ }^{3}$,

Dari definisi di atas, dan di komparasikan dengan pendapat Ibn Hajar. sahabat adalah orang yang pernah bertemu dengan Nabi Saw, dalam keadaan beriman dan meninggal juga dalam keadaan iman. Dalam hal ini, Masuk dalam kategori orang yang pernah ketemu Nabi Saw, adalah orang yang lama bermujalasah baiklama atau sebentar saja bersama beliau, atau orang yang turut berperang maupun tidak, ataupun orang yang tidak pernah melihat beliau dengan alasan tertentu seperti buta dll., ini semua masuk kategori sahabat.

Di luar itu semua di atas, banyak sekali pendapat-pendapat Ulama tentang

\footnotetext{
${ }^{3}$ Muhammad Hasbi Ash Shiddieqy, Sejarah \& Pengantar Ilmu Hadis, Semarang: PT. Pustaka Rizki Putra, 1999. h. 141
}

definisi sahabat, mulai dari bertemu, hidup dimasanya dan mengimaninya. Disini Penulis dapat menyimpulkan dari berbagai definisi sesuai dengan pendapat di atas dan sebagaimana pemaparan Prof. Erfan dalam mendefinisikan sahabat ialah,

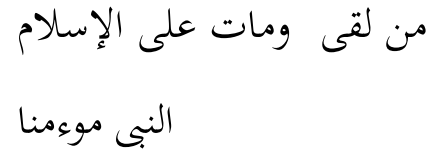

"orang yang pernah bertemu Nabi beriman kepadanya dan meninggal dalam keadaan Islam”. Karena memang tidak dapat dipungkiri, kadang ada seseorang yang selalu bertemu Rasul namun tidak beriman, dan begitupun sebaliknya.

\section{Keadilan sahabat}

HM. Erfan Soebahar, mengkategorikan pemenuhan segi kualitas pribadi ('adil atau 'adalah), bila telah (1) beragama Islam, (2) mukallaf (3) melaksanakan ketentuan Agama [Islam], dan (4) memelihara muru'ah, yang sejalan dengan patokan norma tentang orang jujur yang dapat diterima pemberitaannya ${ }^{4}$.

Senada dengan Erfan, dan $M$. Syuhudi Ismail $^{5}$ memberikan kategori dengan istilah Mayor dan Minor Menunjukkan bahwa kualitas pribadi sangat penting dalam menentukan kesahihan sanad. Disini penulis akan memaparkan kategori dari pemenuhan Kualitas Pribadi ('Adalah)sebagaimana berikut :

a. Beragama Islam

Keislaman merupakan salah satu unsur yang harus dipenuhi oleh

4 Soebahar, H.M. Erfan, Munguak Fakta Keabsahan Al-Sunnah, Jakarta Timur: Prenada Media, 2003. h. 221

5 Ismail, M. Syuhudi, Kaedah Kesahihan Hadis:Telaah Kritis dan Tinjauan dengan pendekatan Ilmu Sejarah, Jakarta: 1995. Hal. 7 
periwayat yang adil. Yakni, ketika periwayat itu menyampaikan riwayat hadis dan bukan menerimanya. Secara logika, ketika informasi yang disampaiakan terkait masalah agama tertentu, maka mustahil ketika yang menyampaikan informasi tersebut dari orang luar agama dimaksud. Maka, hadis yang merupakan sumber hukum Islam seharusnya di riwayatkan oleh orang Islam yang benar-benar taat pada agamanya.

Banyak ayat yang berkaitan dengan hal ini, salah satunya; yaitu QS. Al-hujarat; 6

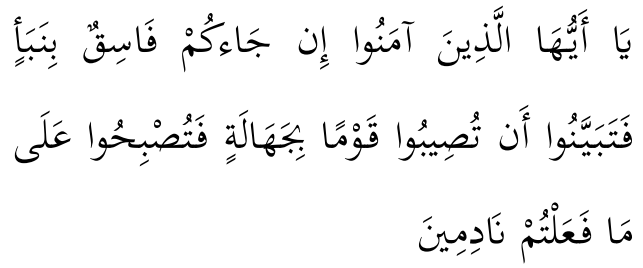

"Hai orang-orang yang beriman, jika datang kepadamu orang fasik membawa suatu berita, maka periksalah dengan teliti agar kamu tidak menimpakan suatu musibah kepada suatu kaum tanpa mengetahui keadaannya yang menyebabkan kamu menyesal atas perbuatanmu itu."

Ulama berbeda pendapat dalam masalah argumen unsur beragama Islam ini. Ayat tersebut memerintahkan agar berita yang dibawa oleh orang fasik diselidiki terlebih dahulu. Sehingga logikanya, ketika orang fasik saja orang harys diselidiki bagaimana dengan orang kafir?, Maka kembali pada paparan awal. Bahwa, orang yang bukan Islam maka ditolak periwayatannya.

Al-Khudhari sebagaimana dikutip oleh Syuhudi menambahkan, sebagian ulama memakai argumen aksioma (al-badihiy) dalam memandang masalah ini. Mereka menyatakan, hadis itu berkenaan dengan sumber ajaran Islam, bagaimana mungkin dapat diterima beritanya tentang sumber ajaran Islam. Hanya orang yang beragama Islam saja yang dapat diterima beritanya tentang sumber ajaran Islam $^{6}$

Selanjutnya, argumen-argumen yang mendasari unsur beragama Islam tidak-lah berasal dari dalil naqli yang sharih saja, tetapi berasal dari pemahaman ayat dan dalil logika. Kendati_argumen-argumen tersebut berbeda-beda, tetapi semua argumen itu saling memperkuat.

Terkait dengan siapa yang dimaksud orang Islam. Syeh Muhammad Al-Ghazali dalam Studi Kritis Hadis menyebutkan bahwa yang dimaksud dengan beragama Islam harus orang yang mantap kepribadiannya dan bertaqwa kepada Allah, serta menolak dengan tegas setiap pemalsuan atau penyimpangan yang terjadi ${ }^{7}$.

b. Bersatatus Mukallaf

Argumen yang mendasari unsur berstatus mukallaf ini tidak ada yang berupa dalil naqly sharih, dalam arti khusus untuk syarat periwayatan hadis. Ulama dalam hal ini menggunakan dalil naqly yang sifatnya umum. Yakni, hadis Nabi yang menyatakan bahwa orang gila,

${ }^{6}$ Ismail, M. Syuhudi ., Kaedah Kesahihan Hadis....... h. 156

7 Al-Ghazali, Muhammad, As- Sunnah AnNabawiyah: baina Ahl Al-Fiqh wa Ahl Al-Hadits, Terj. Muhammad Al-Baqir, Kairo: Dar AsySyuruq, 1998. h. 26 
orang lupa, dan anak-anak terlepas dari tanggung jawab ${ }^{8}$.

Ketentuan yang bersifat umum itu diterapkan juga oleh ulama hadis untuk periwayatan hadis. Hal logis. Karena, orang belum atau tidak memiliki tanggung jawab tidak dapat dituntut apa yang diperbuat atau dikatakan.

Terlepas dari dalil hadis di atas, dalam hal ini dapat dinyatakan pula, bahwa Argumen yang mendasari unsur bersatatus mukallaf adalah argummen aksioma. Dalam pandangan ini, pihak yang tidak berakal atau dalam status tidak berakal, beritanya yang bersifat umum saja tidak dapat dipercaya, apalagi beritanya yang berisi salah satu sumber ajaran agama.

Maka, mukallaf merupakan hal yang wajib di miliki oleh perawi hadis demi menjaga kemuliaan informasi yang bersal dari Rasulullah.

c. Melaksanakan Ketentuan Agama

Ayat QS. Al-hujarat; 6, yang penulis paparkan di atas merupakan salah satu Argumen yang sering digunakan oleh para ulama dalam mendasari unsur melaksanakan ketentuan Agama.

Ayat ini memerintahkan agar berita yang berasal dari orang fasik diteliti (diselidiki) kebenarannya. Ulama berpendapat demikian, tampaknya didasarkan atas pertimbangan bahwa ayat di atas berkenaan dengan berita dalam arti umum, bukan berkenaan dengan

8 Ismail, M. Syuhudi, Kaedah Kesahihan Hadis....... h. 157 berita tentang sumber ajaran Agama. Berita yang sifatnya umum yang dibawa oleh orang fasik haruslah diteliti, maka berita dari orang fasik yang berkenaan dengan sumber ajaran agama islam, dalam hal ini hadis Nabi, harus ditolak.

Kalau kita kaji dari asbabunnuzul nya, maka kata fasik dalam hal ini berarti orang yang berkata bohong 9 . Sebagian ulama mengartikan kata fasik dalam ayat tersebut dengan pendusta. Sebagian ulama lagi mengartikannya dengan orang yang dikenal berbuat dosa. Pendapat-pendapat tersebut tidak bertentangan. Sebab, orang yang suka berbohong adalah orang yang melakukan perbuatan dosa, walaupun tidaklah setiap orang berbuat dosa disebut sebagai fasik ${ }^{10}$.

Kalangan ulama Tafsir ada yang menjelaskan, arti asal Fisq adalah keluar dari sesuatu, sedangkan arti menurut syari'at ialah keluar dari ketaatan kepada Allah. Bentuknya dapat berupa perbuatan kufur atau perbuatan lainnya ${ }^{11}$. Jadi, orang

9 Ayat tersebut turun berkenan dengan laporan bohong yang dibuat al-Walid bin 'Uqbah. Suatu ketika, Nabi mengutus al-Walid bin 'Uqbah untuk menerimakan zakat dari orang-orang Islam di Baniy al-Musytalaq yang telah dijanjikan oleh al-haris bin Dhirar. Sebelum al-Walid dukampung bani al-Mushtalaq, al-Walid merasa takut lalu segera kembali ke Madinah dan melaporkan kepada Nabi bahwa al-Haris tidak mau menyerahkan zakat, bahkan al-Haris akan membunuhnya. Nabi murka dan segera mengutus pasukan untuk memerangi al-Haris dan kaumnya. Dalam pada itu, al-Haris dan kaumnya pada saat itu sedang menunggu utusan yang dijanjikan Nabi untuk menerimakan mereka. Lebih lanjut lihat Syuhudi Ismail, Kesahihan Sanad Hadis, 1995:158

10 Ismail, M. Syuhudi, Kaedah Kesahihan Hadis...... h. 158

${ }^{11}$ Ibn. Kasir, Maktabah Syamilah,I, tt. h. 65 
fasik adalah orang yang tidak melaksanakan ketentuan ketentuan agama Allah. Ketentuan agama Allah itu ada yang berupa perintah ada yang berupa larangan. Pelanggaran terhadap ketentuan agama Allah dapat berstatus sebagai dosa besar dan dapat juga sebagai dosa kecil.

Seperti yang biasa kita temui bahkan kita alami dalam kehidupan kita sehari-hari, bahwasanya orang yang tidak melaksanakan ketentuan Allah (fasik) tidak akan merasa keberatan dalam penyampaikan kabar kebohongan, baik itu sifatnya umum ataupun tidak, dalam kontek ini adalah Hadis Rasulullah. Maka dari itu, dapat dikatakan orang yang tidak menjalankan ketentuan Allah maka tidak dapat dipercaya beritanya, walaupun berita tersebut disandarkan terhadap Nabi.

d. Memelihara Muru'ah

Sebagian Ulama, misalnya Ibn Qudamah, mendasarkan unsur memelihara muru'ah ini pada hadis Nabi yang mengatakan bahwa pernyataan para Nabi yang telah dikenal manusia ialah "bila anda tidak malu, perbuatlah apa yang anda mau" orang yang tidak memiliki rasa malu akan bebas melakukan apa saja yang dikehendakinya. Jadi, muru'ah oleh Ibnu Qudamah disamakan artinya dengan malu ${ }^{12}$.

Kalau kita analisa tentang "malu”, orang pemalu maka akan menjaga muru'ahnya ${ }^{13}$. Orang yang

12 Ismail, M. Syuhudi, Kaedah Kesahihan Hadis....... h. 160

${ }^{13}$ Harga diri yang agamis tercermin sifat muru'ahnya maka akan menghindari kebohongan, karena bohong menurutnya adalah sifat yang tercela, sedangkan orang yang muru'ah akan menghindari sifat-sifat madzmumah (tercela).

Dr. Nuruddin dalam 'Ulumul Hadis I menulis, Memelihara Muru'ah disini maksudnya, meninggalkan segala sesuatu yang isa menjatuhkan harga diri manusia manurut tradisi masyarakat yang benar, seperti kencing di jalan, mencaci maki atau menghina orang lain. Orang seperti ini sebenarnya adalah orang yang mirip amoral, sehingga sukar bagi kita untuk menerima riwayat hadisnya secara $\operatorname{aman}^{14}$

Jadi, Muru'ah (malu) adalah syarat tercitanya sebuah kualitas pribadi seseorang, se cerdas apapun seseorang jika tidak mempunyai sifat muru'ah maka akan berefek pada informasi yang disampaikannya. Orang yang tidak mempunyai sifat muru'ah tidak akan merasa malu dalam menyampaikan berita (hadis) bohong, demi tercapainya sebuah keinginan dan misi yang tersimpan.

3. Pendapat Ulama tentang keadilan Sahabat

Kalau kita melihat pujian Nabi saw. Kepada sahabat-sahabatnya, bagitu juga pujian Allah di beberapa tempat dalam Qur'an, maka dapat dikatakan bahwa Sahabat-sahabat semua bersiafat Adil dalam

14 'Itr, Nuruddin, Manhaj An-Naqd Fii 'Uluum Al-Hadits, terj. H. Endang Soetari AD \& Mulyo, Bandung: PT. Remaja Rosdakarya, 1995. h. 66 
meriwayatkan hadis ( الصحابة كلهم عدل), yakni mereka tidak khianat dan tidak berdusta dalam menyampaikan sabda-sabda dan perjalanan Nabi saw.

Erfan Soebahar menggaris bawahi sahabat generasi pertama dan yang meriwayatkan hadis bagaikan generasi yang langsung "Meneguk air jernih" wahyu kenabian, sehingga beliau mengatakan "Tidak berlebihan bila dijamin kualitas pribadi dan integritas moralnya"

Hal itu, sebab tak kurang dari al-Qur'an sendiri, misalnya, telah menyebutkan keunggulan mereka sebagai: umat terbaik

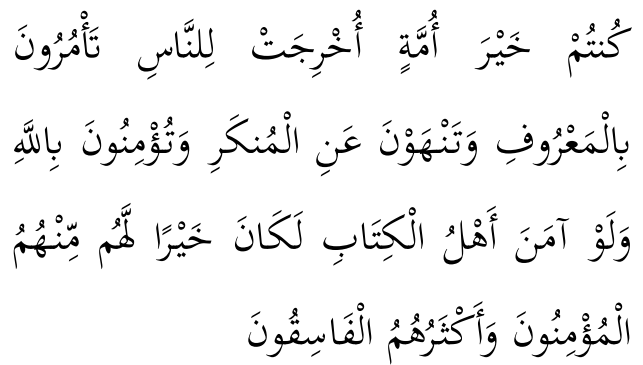

Artinya:

"Kamu adalah umat yang terbaik yang dilahirkan untuk manusia, menyuruh kepada yang ma'ruf, dan mencegah dari yang munkar, dan beriman kepada Allah. Sekiranya Ahli Kitab beriman, tentulah itu lebih baik bagi mereka, di antara mereka ada yang beriman, dan kebanyakan mereka adalah orangorang yang fasik"

Selain itu sebagai umat wasatha (menengah)
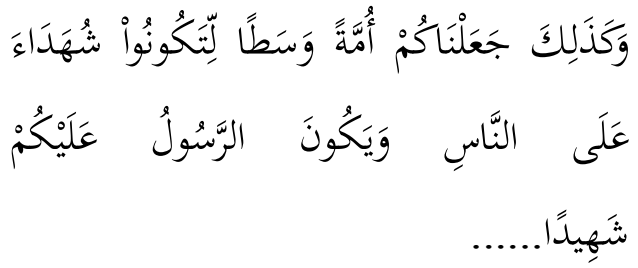

Artinya

"Dan demikian (pula) Kami telah menjadikan kamu (umat Islam), umat yang adil dan pilihan agar kamu menjadi saksi atas (perbuatan) manusia dan agar Rasul (Muhammad) menjadi saksi atas (perbuatan) kamu......"

Dengan sebutan tersebut dalam al-Qur'an menunjukkan kalau sahabat dalam studi hadis termasuk orang yang $a d i l^{15}$, yakni mumpuni kualitas pribadinya sehingga dibebaskan dari perlunya penilaian aspek moral yang meragukan periwayatannya, seperti lazim dilakukan bagi generasi sesudahnya ${ }^{16}$.

Namun terlepas dari konteks sifat dan sebutan al-Qur'an terhadap diri sahabat, mereka itu manusia biasa seperti kita, maka terkadang ada kekeliruan atau kesalahan dalam menyampaikan hadis ataupun riwayat

Teungku M. Hasby menulis dalam bukunya Sejarah dan pengantar ilmu hadis, bahwa seorang sahabi itu, tidaklah harus dipandang adil karena dia dipandang sahabi. Keadaannya harus diteliti. Di antara mereka setelah timbul kekacauan-kekacauan antara sesama mereka.

15 Sebutan adil disini tidak identik dengan maksum sebagaimana keadilan yang dimiliki Nabi sebagai penyampai wahyu, keadilan disini identik dengan kelayakan dalam meriwayatkan hadis. Lebih lanjut lihat Erfan Soebahar, Menguak fakta keabsahan al-Sunnah (Jakarta Timur: Prenada Media, 2003) hal. 223

16 Soebahar, H.M. Erfan,, Munguak Fakta Keabsahan Al-Sunnah, Jakarta Timur: Prenada Media, 2003. h. 223 
Senada dengan pendapat di atas. para sahabat adalah orang yang bersifat adil sampai batas masa terjadi perbedaan dan pemberontakan-pemberotakan diantara mereka. Setelah itu, harus dilakukan penelitian-penelitian tentang sifat adil mereka ${ }^{17}$

Dari banyak pendapat yang disebutkan di atas dapat dikategorikan sebagai berikut :

1. Ahli Sunnah, berpendapat bahwa semua sahabat nabi itu adil, tanpa terkecuali. Pandangan ini mengacu terhadap dalil naqly dan aqly.

Dalil naqly dari pendapat ahli Sunnah sebagian penulis paparkan di atas yaitu, QS. Ali Imran, 3:110, QS. Al-Baqarah, 2:143. Selain itu banyak hadis Nabi yang menjustifikasi terhadap keadilan sahabat.

Abu Umar Ibn Abd al-Bar menyatakan: "dan telah kami cukupkan mengenai hal ihwal mereka (sahabat) berdasarkan ijma' ahl alhaq dari kalangan muslimin, yaitu mereka (sahabat) itu adil"

Para ulama Ahli Sunnah berpendapat, bahwa bersahabat dengan nabi merupakan suatu kemuliaan, karena Nabi itu mempunyai keistimewaan tertentu. Jadi, semua para sahabat itu dipandang adil, baik mereka yang terlibat perang ataupun kekacauan lainnya. Dan jumhur ulama sunnah berpendapat bahwa kaidah الصحابة كلهم عُدُل , yakni dalam konteks periwayatan hadis bukan dalam persaksian atau perkara lainnya. Oleh

17 Al-Khatib, Muhammad Ajaj, As-Sunna Qablat Tadwin, terj. AH. Akrom Fahmi, Beirut: Darul Fikr, 1401 h. 427 karena itu tidak perlu penelitian terhadap mereka.

2. Menurut Madzhab Mu'tazilah, seluruh sahabat itu 'adil, kecuali yang memerangi Ali yang dipandang sebagai orang fasik. Maka ditolak riwayat dan kesaksiannya karena mereka menentang kepala Negara yang sah.

Namun sebagian dari madzhab ada yang berpendirian yaitu menolak riwayat mereka (sahabat) baik yang memerangi Ali maupun berpihak kepada Ali, karena salah satu dari dua golongan ini adalah orang-orang yang dipandang bersalah walaupun tidak dapat dipastikan golongan yang mana $^{18}$.

3. Menurut kaum Khawarij, berpendapat bahwa para sahabat itu harus dinilai adil, sampai timbul kekacauan diantara mereka. Maka sesudah timbul kekacauan itu, haruslah diteliti keadilan mereka ketika menerima riwayatnya. Masih pendapat mereka, sebagian ada yang mengatakan bahwa riwayat mereka (sahabat) dan kesaksiannya apabila perorangan itu harus diterima, akan tetapi apabila menyangkut kesaksian lawannya tidak boleh diterima.

4. Menurut madzhab Syi'ah berpendapat bahwa tidak semua sahabat itu adil. Karena menurut pandangan mereka, sahabat-sahabat seperti Abu Bakar, Umar, Utsman adalah orang-orang yang merampas hak kekhalifaan Ali. Juga mereka mencela Aisyah, Thalhah, Zubair, Muawiyah dan Amr bin 'Ash, yang juga memerangi Ali bin Abi

${ }^{18}$ Khaeruman, Badri, Otentisitas Hadis: Studi Kritik Atas Kajian Hadis Kontemporer, Bandung: PT. Remaja Rosdakarya, 2004. h. 132 
Thallib. Mereka berpendirian bahwa orang yang tidak mengangkat Ali sebagai pemimpi mereka, dianggap telah menghianati wasiat Rasulullah dan keluar dari imam yang sah. Oleh karena itu periwayatannya tidak dianggap sebagai ahli tsiqat dan kepercayaannya.

Ada yang harus digaris bawahi dari pendapat serta interpretasi Ulama atas keadilan sahabat di atas, yaitu keadilan sahabat yang sifatnya individu ataupun kolektif. Pendapat ahli sunnah di atas condong pada kolektifias sahabat, sedangkan yang lainyya (Mu'tazilah, Khawari dan Syi'ah) condong pada individualitas sahabat.

Kalau kita mengakaji hadis Nabi yang diriwayatkan oleh Bukhori Muslim dan lainnya:

$$
\text { خيركم قرنى تم الدين يلوفم تم الدين يلوفم. }
$$

Artinya:

"Sebaik-baiknya kamu sekalian (umat Islam) adalah generasiku, kemudian generasi berikutnya dan kemudian generasi berikutnya lagi"

Hadis tersebut menyebut generasi bukan individu-individu. Ini berarti, bahwa pada umumnya umat Islam yang hidup pada zaman Nabi, yakni para sahabat Nabi, adalah orang-orang yang lebih baik kualitas pribadinya bila dibandingkan dengan orang-orang Islam pada zaman berikutnya. Hal ini kalau dikaji lagi, bukan berarti seluruh sahabat tanpa terkecuali.

Ada contoh sahabat yang disebutkan oleh Prof. Dr. HM. Syuhudi Ismail yang ditulis dalam bukunya "Kaedah Kesahihan Hadis" yaitu Al- walid bin 'Uqbah' ${ }^{19}$ dan al-Asy'as bin Qays ${ }^{20}$. Dengan demikian dapat dinyatakan, bahwa dalil hadis di atas tidak tepat digunakan sebagai argumen tentang adilnya setiap individu sahabat Nabi.

Namun demikian jika kita kembali lagi terhadap apa yang disampaikan oleh Prof. Erfan dalam bukunya. Bahwa, sahabat adalah generasi yang langsung "meneguk air jernih" wahyu kenabian, maka dapat dikatakan para sahabat nabi umumnya bersifat 'Adil, dan dapat dikatakan pula yang tidak bersifat 'Adil hanyalah sedikit.

Cara mengetahui keadilan sahabat saat ini tidak terlalu sulit, karena Ulama sudah menyusun kitab biografi para sahabat Nabi, khususnya para periwayat hadis. Disamping itu, kalangan ulama telah menyusun peringkat keutamaan para sahabat $\mathrm{Nabi}^{21}$. Imam al-Hakim alNaysabury, misalnya, telah menyusun peringkat tersebut kedalam du belas tingkat $^{22}$. Macam-macam peringkat itu, walaupun tidak harus diterapkan secara

19 Al-Walid bi 'Uqbah pernah berbohong kepada nabi , sehubungan dengan perbuatannya tersebut turun ayat al-Qur'an surat al-hujarat/49: 6 . Ayat tersebut tidak menyebut nama, namun sifat. Yaitu sifat faisq. Selain itu dia dikenal sebagai orang yang pembuat bohong dan pemabok. Dan ini bukan sifat yang terpuji bagi orang yang bersifat 'adil. Lebih lengkapnya lihat Syuhudi Ismail, Kaedah Kesahihan Hadis, 1995, h 166

20 Al-Asy'as bin Qays merupakan sahabat nabi yang juga meriwayatkan hadis, dia pernah murtad dan masuk lagi ke dalam Islam

21 Menurut informasi yang diberikan oleh Syuhudi Ismail, slah satu kitab yang membahas ini adalah 'Ushul al-Tafrij wa Dirasat al-sanad, karangan Mahmud al-Thahhan.

${ }^{22}$ Susunan ini dikenal dengan Thabaqat asSahabah. Para ahli hadis berbeda pendapat tentang thabaqat-thabaqat sahabat, ibnu Sa'ad menjadikan 5 thabaqat. Orang lain menjadikan 12 thabaqat. Lebih lanjutnya lihat Teungku Muhammad Hasbi Ash Shiddieqy, Sejarah \& Pengantar Ilmu Hadis, 1999, h. 243 
mutlak, tetapi akan tetap sangat bermanfaat untuk dijadikan acua umum.

e. Kapasitas Intlektual (Dhabith)

Ulama hadist pada umumnya tidak menerangkan Argumen yang mendasari unsur kaedah periwayat bersifat dhabith. Yang mereka kemukakan pada umumnya hanya berkenaan dengan pengertian dhabith sebagai salah satu unsur kaedah kesahehan sanad hadis

Imam Syafi'iy dan lain-lain telah meriwayatkan sabda Nabi yang berbunyi:

$$
\begin{aligned}
& \text { نضرالله عبدا سمع مقالتى فحظها ووعاها } \\
& \text { وأداها فرب حامل فقه غير فقيه ورب حامل } \\
& \text { فقه إلى من هو أفقه منه...........(رواه } \\
& \text { الشافعى عن sابن مسعود) }
\end{aligned}
$$

Artinya.

"(Mudah-mudahan)

Allah

mengkaruniakan keelokan wajah kepada hambaNya yang mendengar sabdaku, kemudian menghafalnya, memeliharanya, dan menyampaikannya (kepada yang lain). Banyak orang yang menerima pengetahuan (hadis) (hanya mampu menghafalnya dan) tidak memahami benar pengetahuan itu; dan banyak orang yang menerima pengetahuan (hadis) itu (kemudian menyampaikannya) kepada orang lain yang (ternyata orang lain itu) lebih paham dari pada orang yang menyampaikannya"

Dari hadis tersebut dapat diperoleh petunjuk, bahwa penerimaan riwayat hadis yang lazim terjadi pada zaman Nabi ialah melalui cara al-sama'. Sedangkan orang yang menyampaikan (hadis adha' alhadis) terlebih dahulu harus hafal dan mampu menyampaikan riwayat hadis yang diterimanya itu kepada orang lain. Periwayat yang hafal, mampu menyampaikan dan paham dengan mendalam akan hadis yang diriwayatkannya, dengan sendirinya lebih baik (berbobot) dari pada periwayat yang hanya haafal dan mampu menyampaikan riwayat hadis saja ${ }^{23}$.

Dengan demikian dapat dinyatakan, bahwa penetapan unsur peri wayat bersifat dhabith didasarkan kepada argumen naqliy, dalam hal ini hadis Nabi. Kalau kita analisa dari hadis Nabi di atas, juga dapat dipahami bahwa, ada periwayat yang hafal dan mampu menyampaikan riwayat hadis, tetapi dia tidak atau bisa dikatakan kurang paham akan kandungannya. Di samping itu, ada pula periwayat yang hafal, mampu menyampaikan hadis yang telah dihafalnya dan paham akan kandungan hadis yang diriwayatkannya.

Ada dua dimensi argumen kalau ditarik lebih mendalam dari hadis tersebut, pertama,Naqly yang kedua Aqly. Paparan tentang dimensi Naqly sudah dibahas di atas, dan yang kedua yaitu dimensi Aqly. Dimensi Aqly mempunyai dua argumen yaitu argumen sejarah dan argumen logika.

Periwayatan hadis dalam sejarahnya lebih banyak berlangsung secara lisan dari pada tertulis, hal ini sebagaimana dibahas pada pemakalah sebelumnya yang berimbas terhadap pembolehan menulis hadis pada masa hidupnya Rasulullah. Sedangkan periwayatan lisan mengharuskan periwayatnya memiliki hafalan yang baik. Periwayat yang tidak

23 Ismail, M. Syuhudi, Kaedah Kesahihan Hadis:Telaah Kritis..... h. 168-169 
memiliki hafalan yang baik, sangat sulit dipercaya keshahihan hadisnya.

Adapun argumen logikanya menurut Prof. Dr. Syuhudi Ismail kaitannya dengan hadis di atas dapat dinyatakan sebagai berikut :

1. Sulit dipercaya seorang periwayat menyampaikan riwayat hadis secara lisan (hafalan), sedangkan dia sendiri tidak hafal tentang hadis yang diriwayatkannya;

2. Sulit dipercaya seorang periwayat yang menyampaikan hadis secara tertulis, sedang dia sendiri tidak

\begin{tabular}{|l|l|c|}
\hline \multicolumn{1}{|c|}{ Dhabith } & \multicolumn{1}{c|}{ 'Adil } & $\begin{array}{c}\text { Ra } \\
\text { nk }\end{array}$ \\
\hline Cerdas & Baik & 1 \\
\hline Cerdas & Tidak Baik & 2 \\
\hline Tidak Cerdas & Baik & 3 \\
\hline Tidak Cerdas & Tidak Baik & 4 \\
\hline
\end{tabular}

memahami apa yang termaktub dalam catatan hadisnya.

3. Periwayat yang paham, hafal dan mampu menyampaikan riwayat hadis lebih dapat dipercaya dari pada periwayat yang hafal dan mampu menyampaikan riwayat hadis tetapi tidak memahami hadis yang diriwayatkannya ${ }^{24}$

Erfan Soebahar mengkategorikan kualitas pribadi (dhabith) dengan tiga syarat. Yaitu, (1) hafal sempurna hadis yang diterima, (2) mampu menyampaikan dengan baik hadis yang dihafalnya itu kepada orang lain, (3) mampu memahami dengan baik hadis yang dihafalnya itu.

Periwayat yang memiliki kualitas pribadi dan kapasitas intelektual di atas, dapat dipandang jujur atau dipercaya

24 Ismail, M. Syuhudi, Kaedah Kesahihan Hadis:Telaah Kritis.... h.169-170 (tsiqah), yakni kompeten. Sedang periwayat yang memiliki kualitas pribadi yang baik ('adil) saja, namun masih menunjukkan tanda-tanda kesan kecerobohan, disebut dengan shaduq ${ }^{25}$. Dengan telah dilakukan penilaian segi kualitas pribadi dan kapasitas intlektualnya, maka keaslian hadis telah dapat diperoleh sehingga diperolehlah bahan yang anda; bagi hujjah untuk diamalkan, maupun bagi historisitas kesejarahan untuk kepentingan konstruksi peristiwa $^{26}$.

Tsiqah merupakan derajat tertinggi perpaduan kualitas sanad, baik dari dari segi kualitas pribadi dan kualitas intlektualnya, sebagaimana tertera pada tabel di bawah ini.

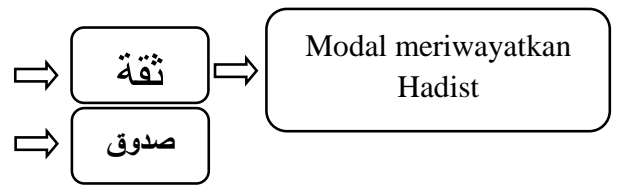

Rawi yang cerdas serta mempunyai sifat ataupun akhlak yang baik maka periwayat yang seperti ini masuk kategori Tsiqah, ketika hanya mempunyai satu sifat saja antar baik dan cerdas maka hal ini masuk kategori shoduq. Klasifikasi seperti ini sangat berimplikasi terhadap hadis yang diriwaytkannya. Perawi yang tsiqah maka kualitas hadisnya shahih, sedangkan perawi yang shaduq kualitas hadisnya hasan, dan begitu seterusnya.

Untuk lebih jauh mengetahui tentang keshahihan hadis maka perlu diadakan pengkajian lebih lanjut tentang

25 Penilaian atau pernyataan bahwa seorang periwayat atau perawi berarti jujur atau dapat dipercaya.

26 Soebahar, H.M. Erfan, Munguak Fakta Keabsahan.... h. 222 
Rijalul hadis, Thabaqatir-Ruwah, Tarikh Rijalul Hadis dan Jarh wa Ta'dil, yang kesemuanya merupakan cabang dari ilmu Hadis.

\section{KESIMPULAN}

Sebagaimana telah dipaparkan di atas. Bahwa, Sahabat adalah orang yang pernah bertemu Nabi beriman kepadanya dan meninggal dalam keadaan Islam. sahabat adalah generasi yang langsung "meneguk air jernih" wahyu kenabian, maka dapat dikatakan para sahabat nabi pada umumnya bersifat 'Adil, dan dapat dikatakan pula yang tidak bersifat 'Adil hanyalah sedikit.

Kaitannya dengan periwayatan hadis, maka kategori pemenuhan segi kualitas pribadi ('adil atau 'adalah), merupakan hal yang sangat urgen dalam ilmu hadist. Yaitu beragama Islam, mukallaf, melaksanakan ketentuan Agama [Islam], serta memelihara muru'ah. Sedangkan kategori Kapasitas Intlektual (dhabith) adalah, hafal sempurna hadis yang diterima, mampu menyampaikan dengan baik hadis yang dihafalnya itu kepada orang lain, dan mampu memahami dengan baik hadis yang dihafalnya itu.

Keterkumpulan dua sifat sebagimana di atas, perawi dapat dipercaya atau dengan kata lain tsiqah sehingga hadis yang keluarkan benar-benar dapat dipertanggung jawabkan. Sedikit berbeda dengan perawi yang mempunyai salah satu sifat saja, maka gret-nya semakin turun dan kredibelitasnya juga semakin kurang dan begitu seterusnya.

\section{DAFTAR PUSTAKA}

Al-Ghazali, Muhammad, As- Sunnah AnNabawiyah: baina Ahl Al-Fiqh wa Ahl Al-Hadits, Terj. Muhammad AlBaqir, Kairo: Dar Asy-Syuruq, 1998. Al-Khatib, Muhammad Ajaj, As-Sunna Qablat Tadwin, terj. AH. Akrom Fahmi, Beirut: Darul Fikr, 1401 H.

A.Qadri Hasan, علم مصطلح الحديث Bandung: CV Penerbit Diponegoro, cet. VIII, 2002

Al-Bani, Mohammad Nasiruddin, Silsilah hadis Dhoif dan Maudu'I (Jakarta :Gema Insani Press, 1995

Departemen Agama RI, Al-Qur'an dan Terjemahannya, Pelita IV. 1985

Ibn. Kasir, Maktabah Syamilah,I, tt

Ismail, M. Syuhudi., Kaedah Kesahihan Hadis:Telaah Kritis dan Tinjauan dengan pendekatan Ilmu Sejarah, Jakarta: 1995.

'Itr, Nuruddin, Manhaj An-Naqd Fii 'Uluum Al-Hadits, terj. Drs. $\mathrm{H}$. Endang Soetari AD \& Drs. Mulyo, Bandung: PT. Remaja Rosdakarya, 1995

Khaeruman, Badri, Otentisitas Hadis: Studi Kritik Atas Kajian Hadis Kontemporer, Bandung: PT. Remaja Rosdakarya, 2004

Nur al-Din Ithr, "manhaj al naqd fi 'ulumil hadits" Maktabah Syamilah, tt.

Soebahar, H.M. Erfan, Munguak Fakta Keabsahan Al-Sunnah, Jakarta Timur: Prenada Media, 2003

Rahman, Fatchur, Ikhtisar Musthalahul Hadis, Bandung: PT. Al-Ma'arif, cet. VII, 1991 
Utsman, Fatimah \& Hasan Asy'ari Ulama'i, Ratu-ratu Hadis,Semarang: ITTAQA Press, 2000

Teungku Muhammad Hasbi Ash Shiddieqy, Sejarah \& Pengantar Ilmu Hadis, Semarang: PT. Pustaka Rizki Putra, 1999.

\section{Pokok-}

Pokok Ilmu Dirayah Hadis Jilid II, Jakarta: Bulan Bintang, cet IV, 1976 